\title{
COCCINELLID PREDATORS OF APHID AND THEIR PHYLOGENETIC ANALYSIS USING COI GENE SEQUENCES
}

\author{
Faria Farhana Rain, Abu Faiz Md. Aslam*, Habiba Sultana Ringki, Nahida Sultana, Nayma Akter and Abdul Jabber \\ Howlader
}

Laboratory of Molecular Entomology, Department of Zoology, Jahangirnagar University, Savar, Dhaka-1342, Bangladesh

*Corresponding author mail: afm.aslam@gmail.com

\begin{abstract}
An extensive survey of aphid predatory Coccinellid beetles (Coleoptera: Coccinellidae) was conducted in Jahangirnagar University campus, Savar during October 2014 to March 2016. Total nine ladybird beetles viz, Adalia bipunctata, Coccinella septempunctata, Coccinella transversalis, Cycloneda munda, Harmonia axyridis, Hippodamia convergens, Micraspis discolor, Scymnus nebulosus, Sticholotis sp. were identified as predators of aphid. Among them, Micraspis discolor was most abundant predator. Biology and bio-control potential of $M$. discolor was studied in laboratory condition on bean infesting aphid (Aphis fabae). The maximum predation was $102 \pm 1.83$ observed in $4^{\text {th }}$ instar larvae of M. discolor. Along with biological study, phylogenetic relationship of ladybird beetles was constructed based on mitochondrial COI gene. Out of nine identified coccinellids, five species showed more conserve region than the rest in alignment. The interspecific genetic distance ranges for nine beetles were very low (0.15-0.24). Higher interspecific genetic diversity recorded for $H$. axyridis. The phylogenetic tree was created and analyzed using both Neighbour Joining and Maximum likelihood methods to define the origin and evolutionary relationships of the species. Molecular analysis demonstrated that evolution of these species has been occurred from a common ancestor. Such study of ladybird beetles would be helpful in biological control program of aphid pest.
\end{abstract}

Key words: Coccinellidae; Aphid; COI gene; Phylogenetic analysis; Evolutionary divergence.

\section{Introduction}

Aphids are broadly recognized as some of the most destructive pests and its distribution is worldwide. Approximately 4000 species of aphids have been described suckling over 250 agricultural and horticultural crops throughout the world (Ali and Rizvi, 2007). Black bean aphid (Aphis fabae, Homoptera: Aphididae) is the most domineering pest of beans and some other crops. Bean aphid invades a large number of fruit, vegetable, agronomic, and ornamental plants. This pest accounts for yield losses ranging from 37 to 90\% (Abate et al., 2000; Ampofo and Massomo,2009). They cause impairment directly by sucking cell sap, secrete honeydew resulting in development of sooty mold on leaves and shoots and secondarily as vectors of certain plant viruses (Difonzo et al., 1997; Kennedy et al., 1962; Raboudi et al., 2002).

Till now, using insecticide is the only option for the farmers or gardeners to control this pest. But due to ban on harmful insecticides by WHO and FAO, carcinogenic effect, environmental pollution, resistance of pest to insecticide lead researchers to search for alternative safe control measures.
Predation is assumed to be one of the major biotic mortality factors dropping insect pest populations, and using them in insect pest management programs has been receiving augmented attention because of the current requirement to reduce the exclusive usage of insecticides for pest control (Luck, 1984; Riudavents and Castane, 1998; Sarmento et al., 2007). Ladybirds are universal predator that feed on a diverse range of foods. Many injurious insects have been successfully controlled by the Coccinellid beetles in agroecosystem (Agarwala et al., 1988). Therefore, an attempt was taken to study the predators of aphid and efficacy of the most effective one.

Mitochondrial genomes are gradually recognized as influential phylogenetic indicators for determining relationships at various hierarchical levels (Gillet et al., 2014; Simon and Hadrys, 2013).Phylogenetic analysis has great impact on classification, forensics, identifying the origin of pathogen and help in conserving nature.

Before deciding to take any pest control action, proper attempt to identification of insect using molecular identification technique would be very effective. This will ultimately help to reduce the risk of damage caused by 
insects. The purpose of this study was to construct the phylogenetic relationship within the ladybird beetles Coccinellidae using COI gene and estimate the divergence from the common ancestor.

\section{Materials and Methods}

\section{Study area and preparation of experimental plots}

Experiments were performed in the Insect Rearing and Experimental Stations (IRES), Savar having geographical location 2352'32.28"N, 90 16'0.06"E from October , 2014 to March, 2016. This area has a good composition of vegetables, fruits, and ornamental trees. The ecological condition supports the prey-predator relationship because this area is free of chemical insecticide usage.

For conducting this research, few small plots of bean (Lablab purpureus) were prepared. In these small plots, chemical fertilizer or insecticides were not used to keep the insects undisturbed. In addition to this other bean gardens of this campus and surroundings were also observed to find any coccinellid beetles.

\section{Coccinellid Predators of Bean Aphid and Their Identification}

Aphids and its natural enemies were keenly observed in the field to make a list of natural enemies of aphid. Predators that were found to predate aphid in the field were collected and taken to the Laboratory of Molecular Entomology, Wazed Miah Science Research Center to study predatory efficacy in laboratory condition. Immature stages that were found to predate aphid were also reared in the laboratory condition to check the life cycle and get the adult stage, which is needed for proper identification. Identification was performed using proper keys (Blackburn,1892; Borror et al., 1981; Omkar and Bind,1993;Omkar and Bind, 1995; Omkar and Bind,1996; Omkar and Pervez,1999; Omkar and Pervez, 2000; Poorani, 2002).All natural enemies were not possible to identify up to species level due to lack of adequate and appropriate keys. In those cases samples were identified up to family or generic level.

\section{Predatory Efficacy of Micraspis discolor in the Laboratory Condition}

M. discolor were observed in the bean crop to feed aphid voraciously. Egg lying of this beetle was followed to collect eggs. Collected eggs were placed on a blotting paper in the petri plate $(60 \mathrm{~mm} \times 15 \mathrm{~mm})$. Petri plates were then transferred to Laboratory. To study its life cycle and predatory efficiency of different life stages, eggs were placed in an incubator with prefixed temperature $28 \pm 2{ }^{\circ} \mathrm{C}$ and light hour of 16 hours. After hatching, the 1st instar larvae were separated individually in different petri plates using soft camel hair brush. Larvae were offered a predetermined number of same sized bean aphids in every 24 hours as their food and their predatory efficacy were recorded. Thus, larval metamorphosis up to adult was observed. Predatory efficacies of the adults were also recorded in the same manner.

\section{Data Analysis}

Development and predation at different life stages of $M$. discolor was recorded with respect to aphid species. SPSS 16.0 software was used for data analysis. COI gene sequence of nine coccinellid beetle species was collected from National Center for Biotechnology Information (NCBI) for their molecular and phylogenetic analysis (http://ncbi.nlm.nih.gov) (Table 1).

Table 1: Info of COI gene sequences from NCBI

\begin{tabular}{ll}
\hline Species name & GenBank accession number \\
\hline Adalia bipunctata & KJ963219.1 \\
Coccinella septempunctata & KM850963.1 \\
Coccinella transversalis & KF541347.1 \\
Cycloneda munda & KM849188.1 \\
Harmonia axyridis & KM849420.1 \\
Hippodamia convergens & KM846002.1 \\
Micraspis discolor & EU392417.1 \\
Scymnus nebulosus & KM850302.1 \\
Sticholotis sp. & JN580799.1 \\
\hline
\end{tabular}

\section{Sequence Alignment and Phylogenetic Analysis}

COI sequences were aligned using ClustalW algorithm with the help of MEGA tools (version 6) with gap opening penalty 15 , gap extensions penalty 6.66 , transition weight 0.5 and delay divergent cutoff $30 \%$ (Kobayashi et al., 1998; Simon and Hadrys, 2013). Multiple sequence alignment images were prepared using jalview, version 2.9 (Von der Schulenburg et al., 2011). For calculation of genetic distances among sequences, we used Kimura's two parameter method (K2P) of base substitution in MEGA 6 (Tamura et al., 2013).

Preliminary phylogenetic analyses were performed with MEGA 6 using both neighbor joining (NJ) and maximum likelihood (ML) tree reconstruction methods (Tamura et al., 2013). The evolutionary history was inferred using the Neighbor-Joining (NJ) method (Saitou and Nei, 1987). The percentage of replicate trees in which the associated taxa clustered together in the bootstrap test (1000 replicates) was shown next to the branches (Felsenstein, 1985). The tree was drawn to scale, with branch lengths in the same units as those of the evolutionary distances used to infer the phylogenetic tree.

The evolutionary history was inferred by using the Maximum Likelihood (ML) method based on the Kimura 2-parameter model (Kimura, 1980).The percentage of trees in which the associated taxa clustered together is shown next to the branches. Initial tree(s) for the heuristic search were obtained automatically by applying Neighbor-Join and 
BioNJ algorithms to a matrix of pairwise distances estimated using the Maximum Composite Likelihood (MCL) approach, and then selecting the topology with superior log likelihood value. The tree was drawn to scale, with branch lengths measured in the number of substitutions per site.

\section{Results}

\section{Coccinellid Predators of Aphid in the Field}

Natural enemies are very important in the control of bean aphids that kill pests. Usually natural enemy populations did not appear in significant numbers until aphids begin to be numerous. In the present experiment, predators of the bean aphid were taken into consideration as natural enemies. Among the most important natural enemies were various predators that were found to feed on aphids. Coccinellid beetle's adults and larvae were most abundant. During the survey period, Coccilenellid ladybird beetles were found to predate aphids and nine (9) predatory beetles were identified (Table 2).

Table 2: Natural enemies of aphid found in JU campus

\begin{tabular}{|c|c|c|}
\hline Order & Family & Species \\
\hline \multirow{9}{*}{ Coleoptera } & \multirow{9}{*}{ Coccinelidae } & Adalia bipunctata \\
\hline & & Coccinella septempunctata \\
\hline & & Coccinella transversalis \\
\hline & & Cycloneda munda \\
\hline & & Harmonia axyridis \\
\hline & & Hippodamia convergens \\
\hline & & Micraspis discolor \\
\hline & & Scymnus nebulosus \\
\hline & & Sticholotis sp. \\
\hline
\end{tabular}

\section{Key characteristics of Coccinellid species}

1. Body broadly oval; pronotum basomedially with a bilobed white spot and each lateral area white and usually with a black spot (pronotum except for lateral margin may be black in melanic forms), elytral pattern highly varied, typically orange with a single large black spot but some with multiple spots or even black with a humeral and a discal red spot; male antenna not modified; Length $(\mathrm{L})=3.5$ to $5.5 \mathrm{~mm}$. Adalia bipunctata

2. Elytron with some spots clearly transverse in shape. Elytron with 3 rounded black spots and a rounded scutellar spot; male genitalia with basal piece more or less evenly narrowed from about middle to narrowly rounded apex; Length $(\mathrm{L})=6.5$ to $7.8 \mathrm{~mm}$..............Coccinella septempunctata

3. Post-coxal plates on abdominal ventrite 1 incomplete, with an associate oblique line; Scutellum black; Elytra bright carmine red or orange or yellow, with an oval subscutellar spot; a large trilobed spot on humeral callus; a transverse band at apical third not reaching lateral margin; three smaller apical spots-one sutural and two lateral, Length $(\mathrm{L})=3.8-6.7 \mathrm{~mm} . . . \ldots$. Coccinella transversalis

4. Elytra orange without black markings; pronotum black with white lateral border within which is a discal spot in each lateral third, this spot may be connected anteriorly and laterally to dark area of disc to form a complete or broken ring-shaped white mark; light yellow-brown legs; Length $(\mathrm{L})=$ 3.5 to $6.2 \mathrm{~mm}$. Cycloneda munda

5. Postcoxal area of first abdominal sternum with an oblique dividing line; elytron subapically with a transverse ridge or raised area; elytron without longitudinal markings, basically with 10 spots arranged in transverse series as follows, scutellar and two subbasal, three medial, three postmedial and one subapical but size of spots varied and spots may be absent on some specimens; large, $\mathrm{L}=7$ to $10 \mathrm{~mm}$..

Harmonia axyridis

6. Elytron usually with six small spots plus a scutellar spot but number of spots may be reduced (especially humeral and basolateral spots may be very small or absent) or elytra immaculate in some individuals; male genitalia with subapical lobes of sipho ovate and rounded apically, basal lobe subparallel medially, apically concavely narrowing to acute apex; Length $(\mathrm{L})=4.2$ to 7.3 mm..................... Hippodamia convergens

7. Convex bodied with orange to red orange elytra; Length $(\mathrm{L})=3.64 \mathrm{~mm}$ to 4.08

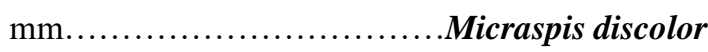

8. Pubescent light reddish-brown species with irregular dark markings on the elytra; a dark median area of the pronotum; Length $(\mathrm{L})=2$ to 2.2 mm..... Scymnus nebulosus

9. Pronotum with anterolateral angle delimited from disc by an oblique line; prosternum anteromedially with a reflexed lobe; maxillary palpus with apical palpomere conical or elongate-oval and pointed apically; postcoxal line short, divided and not forming an arc; Minute, Length $(\mathrm{L})=1.0$ to 1.5 mm........................... Sticholotis sp.

\section{Density of Black Bean Aphid and Micraspis discolor}

As Coccinellids are proven biological control agents, an attempt to count these predators in relation to aphid was taken. Infestation of Aphis fabae in bean plant was very low in early part of August but it increased gradually up to midSeptember. The highest Aphid population was 108.67 per leaf in 9 September. In the meantime predators were also raised. Micraspis discolor were observed in the bean crop to feed aphid voraciously. 
The maximum predation $102 \pm 1.83$ was observed by $4^{\text {th }}$ instar larvae of $M$. discolor followed by the $1^{\text {st }}$ instar, $2^{\text {nd }}$ instar and $3^{\text {rd }}$ instar during the year of study. The first instar larvae of $M$. discolor could consume $20 \pm 0.41$ aphids/day during investigation. The 2 nd instar larvae could devour 39 \pm 0.75 . Similarly the corresponding values for the 3 rd instar and $4^{\text {th }}$ instar larvae were observed as $60.5 \pm 2.57,102 \pm 1.83$ respectively. The total and per day consumption of the aphids by the different instars of this grub was found significant (Table 3).

\section{Multiple Sequences Alignment}

Nine (9) COI gene nucleotide sequences of coccinellid beetles were aligned. Non-conserved (mutated) portions are presented by letter and identical or conserved regions were indicated by dot (Fig. 1).

\section{Pairwise distance}

The number of base differences per site from between sequences is shown. The analysis involved 9 nucleotide sequences. Codon positions included were $1 \mathrm{st}+2 \mathrm{nd}+3 \mathrm{rd}+$ Noncoding. All positions containing gaps and missing data were eliminated. There were a total of 353 positions in the final dataset (Table 4). Genetic distance denotes the mutation among individuals. The lowest genetic distance (0.15) was found in $\mathrm{Hi}$. convergens and highest genetic distance $(0.24)$ was found in $H$. axyridis.

Table 3: Maximum and minimum no of bean aphid (Aphis fabae) consumed by M. discolor under laboratory condition

Days

\begin{tabular}{|c|c|c|c|c|c|c|c|c|}
\hline \multirow[t]{2}{*}{ No. of Observation } & \multicolumn{2}{|c|}{$1^{\text {st }}$ Instar $\quad 2^{\text {nd }}$ Instar } & \multicolumn{2}{|c|}{$3^{\text {rd }}$ Instar } & \multicolumn{3}{|c|}{$4^{\text {th }}$ Instar } & \multirow[t]{2}{*}{ Total } \\
\hline & $\mathbf{1}^{\text {st }}$ & $2^{\text {nd }}$ & $3^{\text {rd }}$ & $4^{\text {th }}$ & $5^{\text {th }}$ & $6^{\text {th }}$ & $7^{\text {th }}$ & \\
\hline 1 & 5 & 9 & 14 & 17 & 16 & 25 & 24 & 110 \\
\hline 2 & 4 & 8 & 11 & 13 & 19 & 31 & 37 & 123 \\
\hline 3 & 6 & 11 & 12 & 18 & 21 & 29 & 31 & 128 \\
\hline 4 & 5 & 11 & 15 & 21 & 20 & 29 & 24 & 125 \\
\hline \multirow[t]{2}{*}{ Mean $\pm \mathrm{SE}$} & $20 \pm 0.41$ & $39 \pm 0.75$ & $52 \pm 0.91$ & $69 \pm 1.65$ & $76 \pm 1.08$ & $114 \pm 1.26$ & $116 \pm 3.14$ & $486 \pm 3.96$ \\
\hline & $20 \pm 0.41$ & $39 \pm 0.75$ & \multicolumn{2}{|c|}{$60.5 \pm 2.57$} & & \multicolumn{2}{|l|}{$102 \pm 1.83$} & \\
\hline
\end{tabular}

Table 4: Interspecific kimura 2 parameter (K2P) genetic distances among 9 species of Coccinellid beetle

$\begin{array}{lllllllll}1 & 2 & 3 & 4 & 5 & 6 & 7 & 8 & 9\end{array}$

\begin{tabular}{|c|c|c|c|c|c|c|c|c|}
\hline \multicolumn{9}{|l|}{ 1. Adalia bipunctata } \\
\hline 2. Coccinella septempunctata & 0.18 & & & & & & & \\
\hline 3. Coccinella transversalis & 0.17 & 0.17 & & & & & & \\
\hline 4. Cycloneda munda & 0.20 & 0.22 & 0.20 & & & & & \\
\hline 5. Harmonia axyridis & 0.16 & 0.17 & 0.16 & 0.24 & & & & \\
\hline 6. Hippodamia convergens & 0.18 & 0.18 & 0.17 & 0.20 & 0.15 & & & \\
\hline 7. Micrapis discolor & 0.19 & 0.18 & 0.17 & 0.21 & 0.20 & 0.19 & & \\
\hline 8. Scymnus nebulosus & 0.20 & 0.17 & 0.22 & 0.23 & 0.16 & 0.17 & 0.22 & \\
\hline 9. Sticholotis sp. & 0.22 & 0.19 & 0.21 & 0.23 & 0.19 & 0.21 & 0.22 & 0.15 \\
\hline
\end{tabular}




\section{Phylogenetic Analysis}

Phylogenetic analysis through the construction of phylogenetic tree was performed by MEGA, version 6 . Both neighbor joining and maximum likelihood tree were built.

In neighbor joining tree, A. bipunctata, $C y$. munda, $C$. transversalis, $M$. discolor and $C$. septempunctata were monophyletic group. A. bipunctata and $C y$. munda were closely related. In context of branch length, $C y$. munda was mostly evolutionary diverse species. Hi. convergens, $H$. axyridis, S. nebulosus and Sticholotis sp. were another monophyletic group. S. nebulosus and Sticholotis sp. were closely related with the high bootstrap value 95\%. A. bipunctata, Cy. munda, and C. transversalis showed lowest bootstrap value only $9 \%$ (Fig. 2).
Adalia/1-658 Coccinella/1-658 Coccinella/1-659 Cycloneda/1-609 Harmonia/1-658 Hippodamia/1-658 Micraspis/1-583 Scymnus/1-636 Sticholotis/1-440

Consensus

Adalia/1-658 Coccinella/1-658 Coccinella/1-659 Cycloneda/1-609 Harmonia/1-658

Hippodamia/1-658 Mcraspis/1-583 Scymnus/1-636 Sticholotis/1-440

Consensus

Adalia/1-658 Coccinella/1-658 Coccinella/1-659 Cycloneda/1-609 Harmonia/1-658 Hippodamia/1-658 Micraspis/1-583 Scymnus/1-636 Sticholotis/1-440

Consensus

Adalia/1-658 Coccinella/1-658 Coccinella/1-659 Cycloneda/1-609 Harmonia/1-658 Hippodamia/1-658 Mcraspis/1-583 Scymnus/1-636 Sticholotis/1-440

Consensus

Adalia/1-658

Coccinella/1-658 Coccinella/1-659 Cycloneda/1-609 Harmonia/1-658 Hippodamia/1-658 Micraspis/1-583 Scymnus/1-636 Sticholotis/1-440

Consensus

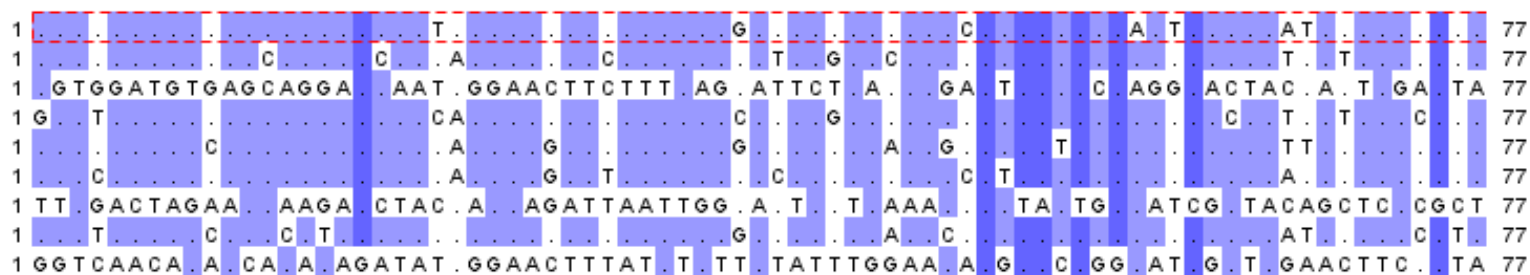
IGGTCAACA A CA A AGATAT GGACTTTAT TT TATTTGGAA G G
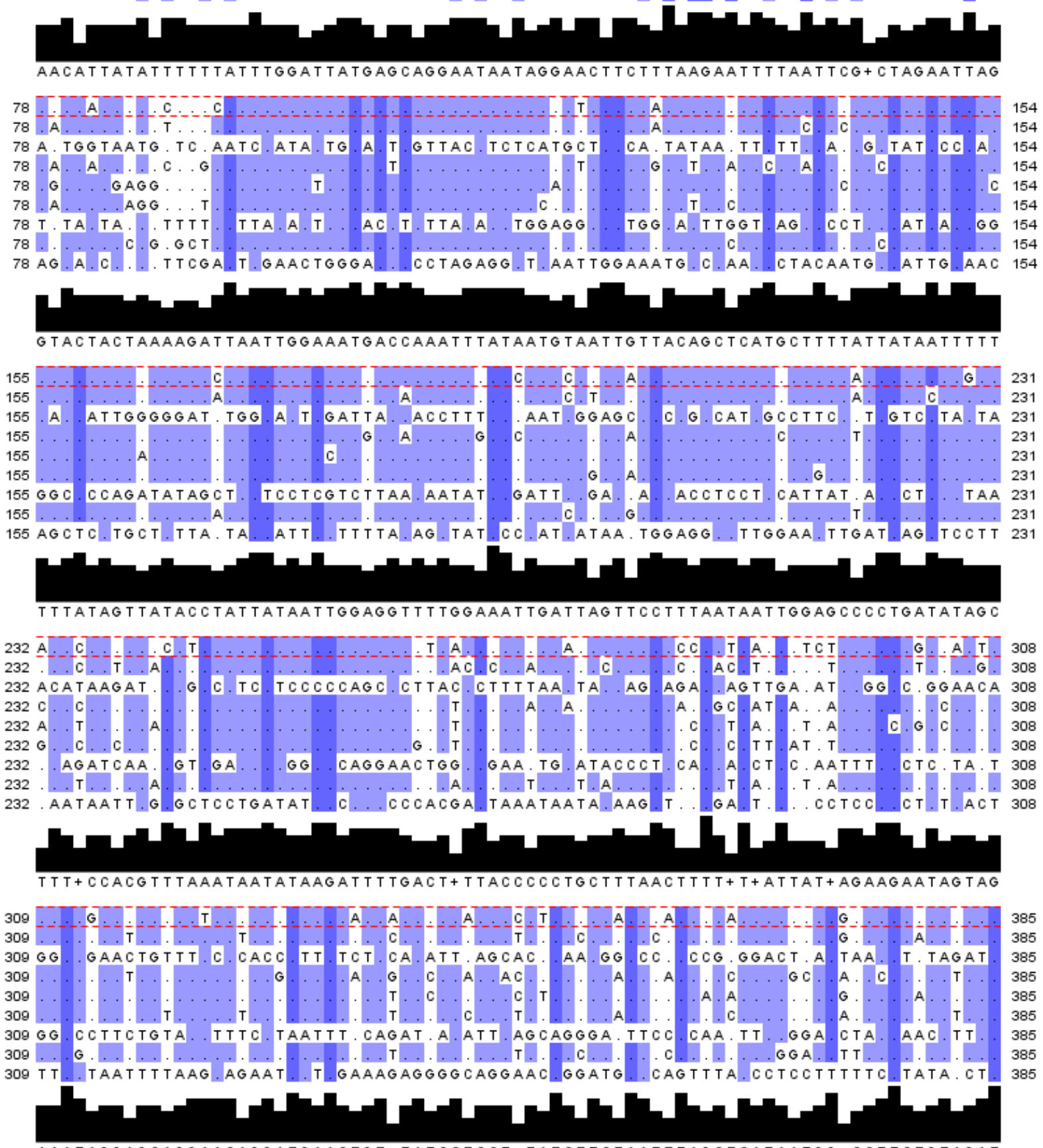

AAATAGGAGCAGGAACAGGATGAACTGT+ TATCCTCCT+ TATCTTCTAATTTAGCTCATAATGG+CCTTCTGTAGAT

This paper can be downloaded online at http://ijasbt.org \& http://nepjol.info/index.php/IJASBT 
Adalia/1-658 Coccinella/1-658

Coccinella/1-659 Cycloneda/1-609 Harmonia/1-658

Hippodamia/1-658 Mcraspis/1-583

Scymnus/1-636 Sticholotis/1-440

Consensus

Adalia/1-658 Coccinella/1-658 Coccinella/1-659 Cycloneda/1-609 Harmonia/1-658 Hippodamia/1-658 Micraspis/1-583

Scymnus/1-636 Sticholotis/1-440

Consensus

Adalia/1-658 Coccinella/1-658 Coccinella/1-659 Cycloneda/1-609 Harmonia/1-658 Hippodamia/1-65 Micraspis/1-583 Scymnus/1-636 Sticholotis/1-440

Consensus

Adalia/1-658 Coccinella/1-658 Coccinella/1-659 Cycloneda/1-609 Harmonia/1-658 Hippodamia/1-658 Micraspis/1-583

Scymnus/1-636 Sticholotis/1-440

Consensus
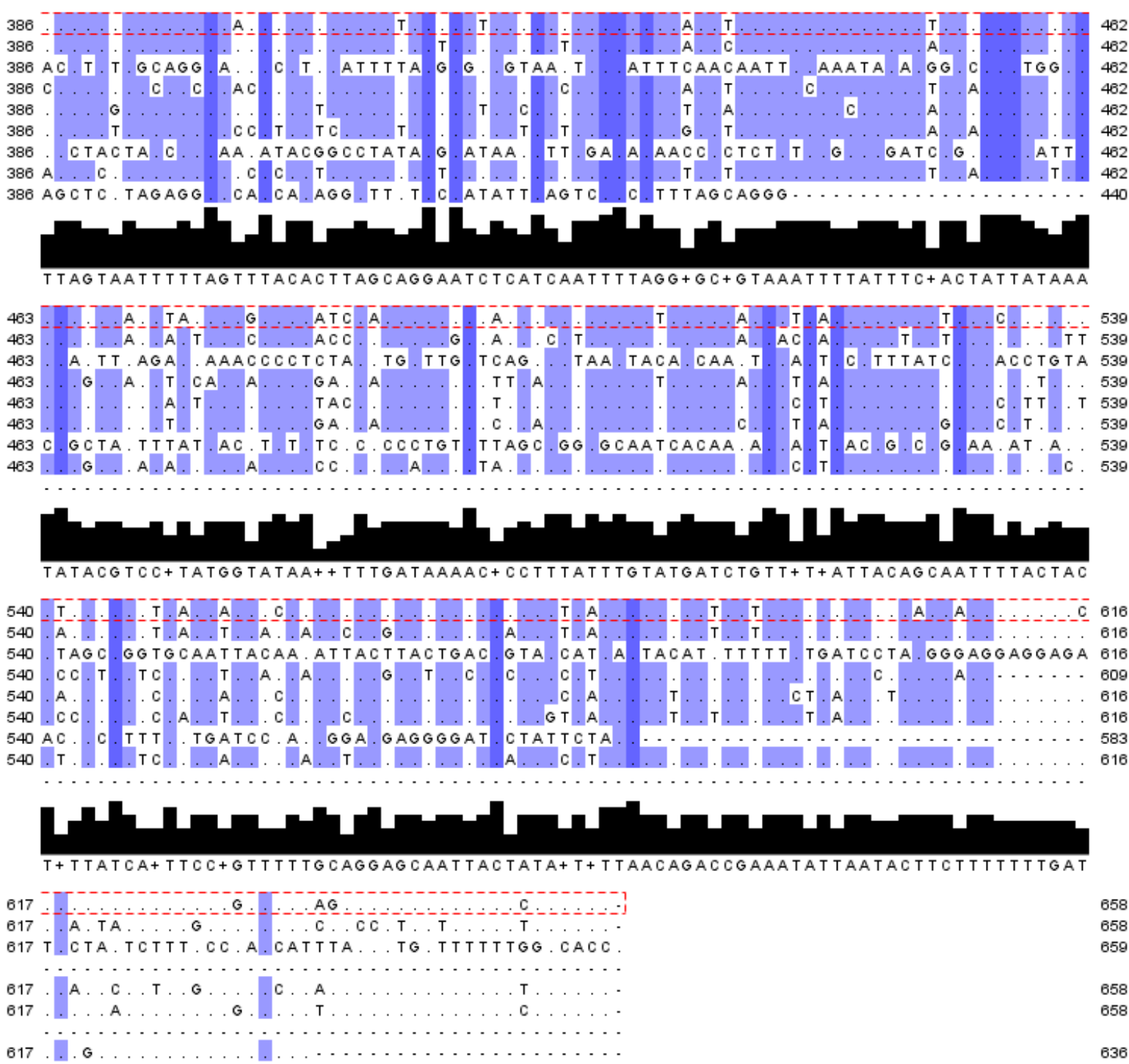

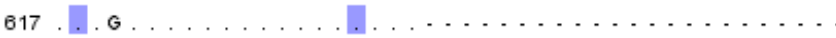

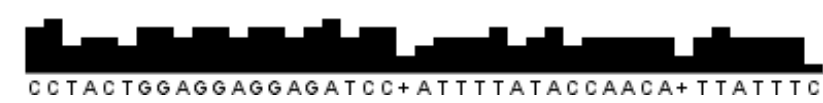

Fig. 1: Multiple sequence alignment of nine predatory Coleopteran beetles. Dots denote the conserved region and color means the $60 \%$ conserved portion among these nine nucleotide sequences.

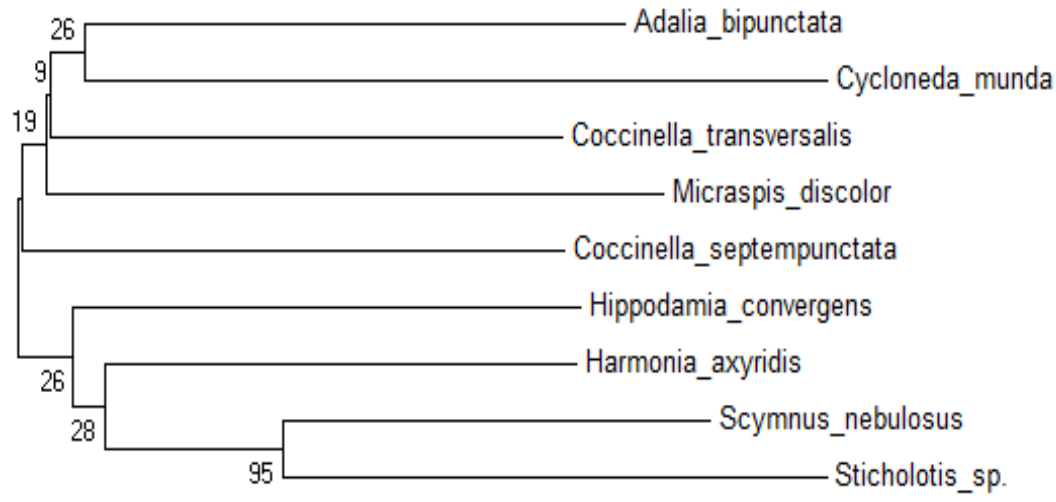

0.02

Fig. 2: Evolutionary relationship of selected Coccinellidae beetles using Neighbor-joining method. The optimal tree with the sum of branch length $=0.80976893$. Codon positions included were 1 st +2 nd $+3 r d+N o n c o d i n g$. All positions containing gaps and missing data were eliminated. There were a total of 353 positions in the final dataset. 


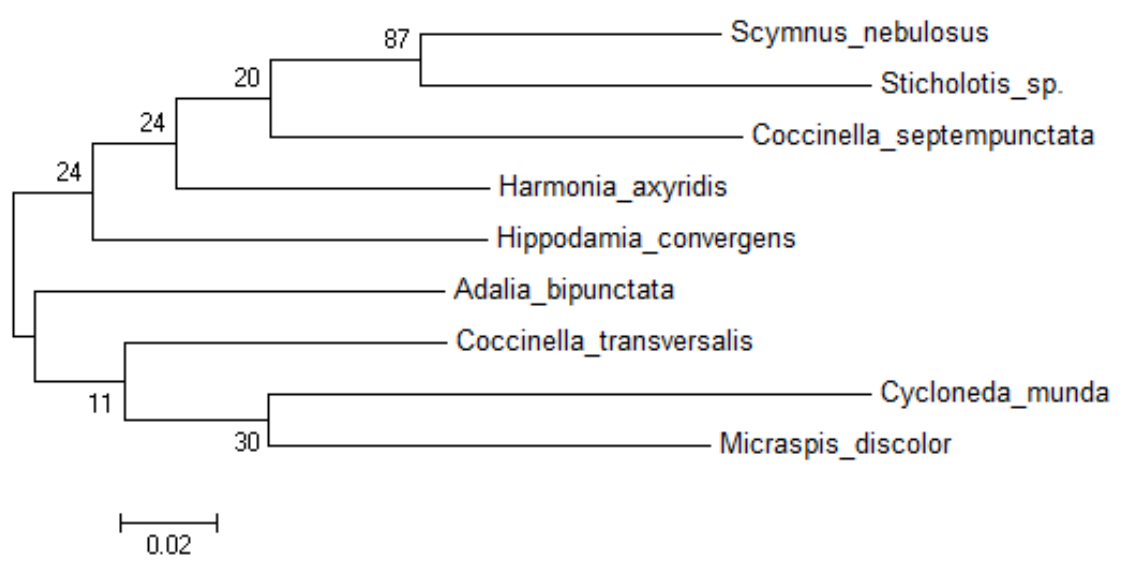

Fig. 3: Evolutionary relationships of the selected Coccinellid beetle species using Maximum likelihood method. The tree with the highest log likelihood (-1850.9690).Codon positions included were 1st+2nd+3rd+Noncoding. All positions with less than $95 \%$ site coverage were eliminated. Fewer than 5\% alignment gaps, missing data, and ambiguous bases were allowed at any position. There were a total of 353 positions in the final dataset.

In maximum likelihood, S. nebulosus, Sticholotis sp., $C$. septempuntata, $H$ axyridis, $H i$. convergens were monophyletic group. S. nebulosus, Sticholotis sp., were closely related with $87 \%$ bootstrap value shared a common ancestor. A. bipunctata, C. transversalis, Cy. munda, M. discolor were another monophyletic group. In context of branch length, Sticholotis sp and Cy. munda were mostly evolutionary distant species from common ancestor (Fig. 3).

The bar at the bottom of the Fig. 2 and 3 provides a scale for the genetic change. In this case the line segment with the number '0.02' shows the length of branch that signifies an amount genetic change of 0.02 .

\section{Discussion}

The high incidence of Black Bean Aphid might due to succulent nature of the plant (Zelena et al., 2004). Certain wasps, lady beetles (both larvae and adults), and larvae of lacewings and syrphid flies prey on aphids (Anonymous. 2000).

In the present study, the maximum predation $102 \pm 1.83$ was observed by $4^{\text {th }}$ instar larvae of $M$. discolor followed by the $1^{\text {st }}$ instar, $2^{\text {nd }}$ instar and $3^{\text {rd }}$ instar during the year of study. The total and per day consumption of the aphids by the different instars of this grub was found important.

We observed nine coccinellid beetle found to predate the aphid population. Adalia bipunctata, Coccinella septempunctata, Coccinella trasversalis, Cycolneda munda, Harmonia axyridis, Hippodamia convergens, Micraspis discolor, Scymnus nebulosus, Sticholotis sp. other researchers also proved that these predator species differ in their capacity to consume aphids and have high impact on aphid populations. Saleem et al. (2014) evaluated predation efficacy of Menochilus sexmaculatus. The results expose $4^{\text {th }}$ instar larvae with the highest predation presentation while the $1^{\text {st }}$ larval instars informed the lowest. Larvae of $C$. septempuncata have a much greater capacity for predation (Turanlı and Yoldaş, 2002; Yoldaş, 1994;
Yoldaş and Sanjrani ,1999). C. septempunctata is a wellknown predator of black bean aphid (Hodek et al., 1965). A. bipunctata and $C$. septempunctata have been used experimentally in Finland for aphid control on chrysanthemums and roses (Mahr et al., 2010). Asian lady beetle $H$. axyridis is used for protecting vegetable and green crops from aphids in greenhouses of the Primorskii krai and northwestern region of the Russian Federation (Kozlova, 2008).

For accurate identification of various taxa, DNA barcoding is most promising approaches that uses molecular instead of morphological data (Blaxter, 2003). The advantage of molecular approach in determining phylogenetic relationships over the more classical approaches is that the differences can be established readily. To understand the close relationship among organisms, sequence alignment is very important method_in bioinformatics for visualizing the relation (Kashmeera and Shudhikumar, 2015).

Nine coccinellid predator's COI gene sequences were collected from NCBI. The purpose of the study was to evaluate the phylogenetic relationship among coccinellid species._Among the studied sequences, the lowest nucleotide sequences were found in Sticholotis sp (440) and the highest nucleotide sequences were found in $C$. transversalis (683). A. bipunctata, C. septempunctata, $C y$. munda, $H$. axyridis, $S$. nebulosus showed comparatively high conserved region than $C$. transversalis, $M$. discolor and Hi. convergens and Sticholotis sp in COI gene sequences.60\% conserved region were showed in color region (Fig. 1).

The interspecific genetic distances for the nine species included in this study had range from 0.15 to 0.24.Comparatively higher interspecific genetic diversity recorded for $H$. axyridis (Table 4).

In Phylogenetic analysis, the constructions of trees were done by both Neighbor joining (NJ) and Maximum 
likelihood (ML) tree. In Neighbour-joining tree method, $A$. bipunctata, Cy. munda, C. transversalis, $M$. discolor and $C$. septempunctara belonged to same cluster. In this cluster, $A$. bipuncata and $C y$. munda showed higher bootstrap values than others. Hi. convergens, H. axyridis. S. nebulosus and Sticholotis sp belonged to another cluster. In Maximum likelihood tress, two clusters were found. One cluster consisted of S. nebulosus, Sticholotis sp, C. septempunctata, $H$. axyridis and $H i$. convergens. A. bipuncata, $C$. transversalis, Cy. munda and $M$. discolor belonged to another cluster. In both trees, S. nebulosus and Sticholotis $s p$ were closely related to each other and showed highest bootstrap values. In context of branch length, $C y$. munda was mostly distant from common ancestor in both tree constructions (Fig. 2 and Fig. 3).

Very limited molecular experiments have been stated on Coccinellidae, matched to other insect groups in the world. $\mathrm{Fu}$ and Zhang (2006) was the pioneer of molecular systematic analyses of family Coccinellidae. Kobayashi et al. (1998) studied Cytochrome Oxidase I (COI) gene region of Epilachninae. Von der Schulenburg et al. (2011) also studied on coccinellidae and concluded that extreme lengths and length variation of Internal Transcribed Spacer Region I gene region has impact of species divergence. Phylogenetic analysis is important because it enriches our understanding of how genes, genome, species evolve. It also enables us to predict how they will change in upcoming generation.

Ainsley et al. (2011) conducted molecular analysis in beetle family and improved phylogenetic resolution and support for early diverging lineages. They properly distinguish the subfamilies Microweisinae and Coccinellidae. Bernhard et al. analyzed coccinellid phylogeny according to COI gene sequence. They found monophyly of coccinellidae family. The phylogenetic relationships of the three major species groups of Coleopteran were inferred using the simultaneous analysis of $642 \mathrm{bp}$ of the most conserved part of mitochondrial DNA (mt DNA) cytochrome oxidase I (COI) (Bernhard et al., 2009).

\section{Conclusions}

Coccinellid beetles showed high predation efficiency especially $M$. discolor was found effective predator of bean aphid (Aphis fabae), which could be recommended to use in the field level after more screening. The phylogenetic analysis has led to confirm that evolution has been occurred from a common ancestor and the species are closely related to each other. That means our studied other beetles also could be recommended as effective predator of bean aphid but need further experiment to confirm this. Phylogenetic analysis and multiple sequence alignment both support the relationship of Coccinellid beetles. Proper identification of ladybird beetle would be effective for aphid control program in agriculture.

\section{Acknowledgement}

This work was partially supported by grants from Higher Education Quality Enhancement Project (CP-3424), a project of University Grants Commission of Bangladesh and Ministry of Education, Bangladesh.

\section{References}

Abate T, Van Huis A and Ampofo JK (2000) Pest Management Strategies in Traditional Agriculture: An African Perspective. J. Ann. Rev. Entomo. 45: 631-659. DOI: 10.1146/annurev.ento.45.1.631

Agarwala BK, Das S and Senchowdhuri M (1988) Biology and food relation of Micraspis discolor an aphidophagous coccinellid in India. J. Aphido. 2 (1-2): 7-17.

Ainsley ES, Jose, AG, Jiahui L and Adam S (2011) Phylogeny, classification and evolution of ladybird beetles (Coleoptera: Coccinellidae) based on simultaneous analysis of molecular and morphological data. Mol. Phylo. Evol. 60 (1): 137-151. DOI:10.1016/j.ympev.2011.03.015

Ali A and Rizvi PQ (2007) Development and Predatory Performance of Coccinella septempunctata L. (Coleoptera: Coccinellidae) on Different Aphid Species. J. Biol. Sci. 7(8): 1478-1483. DOI: $10.3923 /$ jbs.2007.1478.1483

Ampofo JK and Massomo SM (2009) Some Cultural Strategies for Management of Bean Stem Maggots (Diptera: Agromyzidae) on Beans in Tanzania// Bioline International. - African Crop Science Society. DOI: tspace.library.utoronto.ca/handle/1807/20304

Anonymous (2000) Unic. Of California. Division of Agriculture and Natural Resources. Pest notes: Aphids. Available: www.ipm.ucdavis.edu.

Bernhard D, Ribera I, Komarek A and Beutel RG (2009) Phylogenetic analysis of Hydrophiloidea (Coleoptera: Polyphaga) based on molecular data and morphological characters of adults and immature stages. Ins. Sys. Evol. 40: 3-14. DOI 10.1163/187631209X416741

Blackburn T (1892) Further notes on Australian Coleoptera, with descriptions of new genera and species, XII. Trans. R. Soc. S. Aust. 15(2): 2207-261.

Blaxter ML (2003) Molecular systematics: counting angels with DNA. Nat. 421: 122-124. DOI: 10.1038/421122a

Borror DJ, Delong DM and Triplehorn CA (1981) Introduction to the study of insects.CBS college publishing. ISBN 0-03043531-5

Difonzo CD, Ragsdale DW, Radcliffe EB, Gumestad NC and Secor GA (1997) Seasonal abundance of aphid vectors of potato virus $\mathrm{Y}$ in the Red River Valley of Minnesota and North Dakota. J. Eco. Entomo. 90: 824-831. DOI: 10.1093/jee/90.3.824

Felsenstein J (1985) Confidence limits on phylogenies: An approach using the bootstrap. Evol. 39: 783-791. DOI: $10.2307 / 2408678$

Fu J and Zhang YC (2006) Sequence analysis of mtDNA - COI gene and Molecular Phylogeny on twenty seven Species of 
Coccinellids (Coleoptera: Coccinellidae). Entomotaxo. 28(3): 179-185.

Gillett CPDT, Crampton-Platt A, Timmermans MJTN, Jordal B, Emerson BC and Vogler AP (2014) Bulk de novo mitogenome assembly from pooled total DNA elucidates the phylogeny of weevils (Coleoptera: Curculionoidea). Mol. Bio. Evol. 31: 2223-2237. DOI: 10.1093/molbev/msu154

Hodek I, Novak K, Skuhravy V and Holman J (1965) The predation of Coccinella septempunctata $\mathrm{L}$. on Aphis fabae Scop on sugar beet. Acta. Entomo. Bohem. 62: 241-253.

Kashmeera NA and Shudhikumar AV (2015) Preliminary study of Identification of spiders using Mitochondrial DNA. Int. J. Rec. Sci. Res. 6(8): 5741-5743.

Kennedy JS, Day MF and Eastop VF (1962) A Conspectus of Aphids as Vectors of Plant Viruses. Commonwealth Institute of Entomology, London.

Kimura MA (1980) simple method for estimating evolutionary rate of base substitutions through comparative studies of nucleotide sequences. J. Mol. Evol. 16:111-120. DOI: 10.1007/BF01731581

Kobayashi N, Tamura K, Aoutsuka T and Katakura H (1998) Molecular phylogeny of twelve Asian species of Epilachnine ladybird beetles (Coleoptera: coccinelliddae) with notes on the directions of host shifts. Zool. Sci. 15: 147-151. DOI: $10.2108 / \mathrm{zsj} .15 .147$

Kozlova EG (2008) Biological Protection of Green Crops during Cultivation of Lettuce Lines. Gavrish,9.

Luck RF (1984) Principles of arthropod predation. Eco. Entomo. 497-530.

Mahr SR, Cloyd RA, Mahr DL and Sadof CS (2010) Biological control of insects and other pests of greenhouse crops. North Central Regional. University of WisconsinExtension, Cooperative Extension. North central regional publication 581: 108.

Omkar and Bind RB (1993) Records of aphid natural enemies complex of Uttar Pradesh. II. The coccinellids. J. $A d v$. Zool. 14: 96-99.

Omkar and Bind RB (1995) Records of aphid natural enemies complex of Uttar Pradesh IV. The coccinellids. J. Adv. Zool. 16: 67-71.

Omkar and Bind RB (1996) Records of aphid natural enemies complex of Uttar Pradesh .V. The coccinellids. J. Adv. Zool. 17: 44-48.

Omkar and Pervez A (1999) New Record of coccinellids from Uttar Pradesh. I. J. Adv. Zool. 20: 106-112.

Omkar and Pervez A (2000) New Record of coccinellids from Uttar Pradesh. II. J. Adv. Zool. 21: 43-47.

Poorani J (2002) An annotated checklist of the Coccinellidae (Coleoptera) (excluding Epilachninae) of the Indian subregion. Orien. Ins. 36: 307-383.
Raboudi F, Ben Moussa A, Makni H, Marraakchi M and Makni M (2002) Serological detection of plant viruses and host plant in Tunisia. EPPO. Bull. 32: 495-498.

Riudavents J and Castane C (1998) Identification and evaluation of native predators of Frankliniella occidentalis (Thysanoptera: Thripidae) in the Mediterranean. Environ. Entomo. 27: 86-93. DOI: 10.1093/ee/27.1.86

Saitou N and Nei M (1987) The neighbor-joining method: A new method for reconstructing phylogenetic trees. Mol. Biol. Evol. 4: 406-425.

Saleem M, Hussain D, Anwar H, Saleem M, Ghouse G and Abbas M (2014) Predation Efficacy of Menochilus sexmaculatus Fabricus (Coleoptera: Coccinellidae) against Macrosiphum rosae under laboratory conditions. J. Entomo. Zool. Stud. 2 (3): 160-163.

Sarmento RA, Venson M, Pallini A, Oliveira EE and Janssen A (2007) Use of odours by Cycloneda sanguinea to assess patch quality. Entomol. Experi. Et. Appli. 124: 313-318. DOI: $10.1111 / \mathrm{j} .1570-7458.2007 .00587 . \mathrm{x}$

Simon S and Hadrys H (2013) A comparative analysis of complete mitochondrial genomes among Hexapoda. Mol. Phylo. Evol. 69(2): 393-403. DOI: 10.1016/j.ympev.2013.03.0

Tamura K, Stecher G, Peterson D, Filipski A and Kumar S (2013) MEGA6: Molecular Evolutionary Genetics Analysis Version 6.0. Mol. Phylo. Evol. 30(12): 27252729. DOI: $10.1093 / \mathrm{molbev} / \mathrm{mst} 197$

Turanlı D and Yoldaş Z (2002) Investigations on some biological aspects of Aphidoletes aphidimyza (Rondani) (Diptera: Cecidomyiidae). Türk. Entomo. Derg. 26 (1): 11-20.

Von der Schulenburg JHG, Hancock JM, Pagnamenta A, Sloggett JJ, Majerus MEN and Hurst DD (2011) Extreme length and length variation in the first ribosomal Internal transcribed spacer of ladybird beetles (Coleoptera: Coccinellidae). Mol. Biol. Evol. 18: 648-660. DOI: 10.1093/oxfordjournals.molbev.a003845

Wiedenmann RN and Smith JW (1997) Attributes of the natural enemies in ephemeral crop habitats. Biol. Cont. 10: 16-22. DOI: 10.1006/bcon.1997.0544

Yoldaş Z (1994) Studies on the biology of Chrysoperla carnea (Stephens) (Neuroptera: Chrysopidae) feeding on two different preys, 375-380. Proceedings of the 3rd Turkish National Congress of Biological Control. 575.

Yoldaş Z and Sanjrani W (1999) "Investigation of the effect of two different degrees of temperature on the consumption capacity of Coccinella septempunctata L. (Col., Coccinellidae) feeding on Macrosiphum euphorbiae (Thomas) (Hom., Aphididae), 427-434". Proceedings of the 4th Turkish National Congress of Biological Control. 633.

Zelena E, Zeleny F and Holman J (2004) Sulfur Nutrition of Plants and their Resistance to Aphids [Conference] // Slovak and Czech Plant Protection Conference. - Nitra: Acta. Fyto. Zoot. 7: $360-36$ 